\title{
Acta
Biochimica
Polonica
}

Vol. 52 No. 1/2005

$167-178$

QUARTERLY

\section{Inhibition of DNA repair glycosylases by base analogs and tryptophan pyrolysate, Trp-P-1 ${ }^{\star}$}

\author{
Elżbieta Speina ${ }^{1}$, Jarosław M. Cieśla ${ }^{1}$, Maria-Anna Grąiewicz ${ }^{1}$, Jacques Laval ${ }^{2}$, \\ Zygmunt Kazimierczuk ${ }^{3}$ and Barbara Tudek ${ }^{1 凶}$
}

${ }^{1}$ Department of Molecular Biology, Institute of Biochemistry and Biophysics, Polish Academy of Sciences, Warszawa, Poland; ${ }^{2}$ Groupe "Reparation de l'ADN," CNRS Unite Mixte de Recherche 8126, Institut Gustave Roussy, Villejuif Cedex, France; ${ }^{3}$ Laboratory of Experimental Pharmacology, Medical Research Center, Polish Academy of Sciences, Warszawa, Poland

Received: 17 January, 2005; accepted: 28 February, 2005

Key words: DNA repair enzymes, formamidopyrimidine DNA glycosylase, inhibitors, base analogs, Trp-P-1

DNA base analogs, $2,4,5,6$-substituted pyrimidines and 2,6 -substituted purines
were tested as potential inhibitors of $E$. coli Fpg protein (formamidopyrimidine-DNA
glycosylase). Three of the seventeen compounds tested revealed inhibitory proper-
ties. 2 -Thioxanthine was the most efficient, inhibiting $50 \%$ of 2,6 -diamino-4-hy-
droxy-5 $N$-methyl-formamidopyrimidine (Fapy-7MeG) excision activity at $17.1 \mu \mathrm{M}$
concentration. The measured $K_{i}$ was $4.44 \pm 0.15 \mu \mathrm{M}$. Inhibition was observed only
when the Fpg protein was first challenged to its substrate followed by the addition of
the base analog, suggesting uncompetitive (catalytic) inhibition. For two other com-

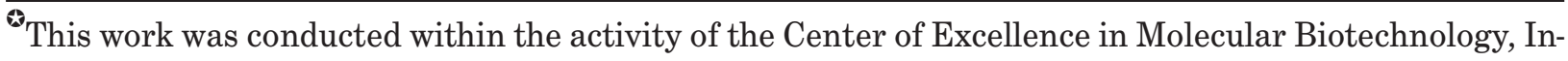
stitute of Biochemistry and Biophysics, PAS (WP10) and was supported (Z.K.) by the Foundation for the Development of Diagnostic and Therapy, Warsaw, Poland

Present address: Laboratory of Molecular Genetics, NIEHS, NIH, Research Triangle Park, 27709, NC, U.S.A.

${ }^{凶}$ Correspondence to: B. Tudek, Department of Molecular Biology, Institute of Biochemistry and Biophysics, Polish Academy of Sciences, A. Pawińskiego 5a, 02-106 Warszawa, Poland; tel.: (48 22) 592 3334; fax: (48 22) 658 4636; e-mail address: tudek@ibb.waw.pl

Abbreviations: AP, apurinic/apyrimidinic; dRPase, deoxyribose 5-phosphatase; 7EtG, 7-ethylguanine; $\varepsilon A, 1, N^{6}$-ethenoadenine; FapyA, 4,6-diamino-4-hydroxy-5-formamidopyrimidine; FapyG, 2,6-diamino4-hydroxy-5-formamidopyrimidine; Fapy-7MeG, 2,6-diamino-4-hydroxy-5N-methyl-formamidopyrimidine; 3MeA, 3-methyladenine; 7MeG, 7-methylguanine; MNU, methylnitrosourea; $\left[{ }^{3} \mathrm{H}\right] \mathrm{MNU}-\mathrm{DNA}$, DNA alkylated with $\left[{ }^{3} \mathrm{H}\right]$ methylnitrosourea; 8-oxoG, 8-oxoguanine; Trp-P-1, 3-amino-1,4-dimethyl$5 H$-pyrido[4,3-b]indole.
} 
pounds, 2-thio- or 2-oxo-4,5,6-substituted pyrimidines, $\mathrm{IC}_{50}$ was only $343.3 \pm 58.6$ and $350 \pm 24.4 \mu \mathrm{M}$, respectively. No change of the Fpg glycosylase activity was detected in the presence of Fapy-7MeG, up to $5 \mathrm{mM}$.

We also investigated the effect of DNA structure modified by tryptophan pyrolysate (Trp-P-1) on the activity of base excision repair enzymes: Escherichia coli and human DNA glycosylases of oxidized (Fpg, Nth) and alkylated bases (TagA, AlkA, and ANPG), and for bacterial AP endonuclease (Xth protein). Trp-P-1, which changes the secondary DNA structure into non-B, non-Z most efficiently inhibited excision of alkylated bases by the AlkA glycosylase $\left(\mathrm{IC}_{50}=1 \mu \mathrm{M}\right)$. The ANPG, TagA, and Fpg proteins were also inhibited although to a lesser extent $\left(\mathrm{IC}_{50}=76.5 \mu \mathrm{M}, 96 \mu \mathrm{M}\right.$, and 187.5 $\mu \mathrm{M}$, respectively). Trp-P-1 also inhibited incision of DNA at abasic sites by the $\beta$-lyase activity of the Fpg and Nth proteins, and to a lesser extent by the Xth AP endonuclease. Thus, DNA conformation is critical for excision of damaged bases and incision of abasic sites by DNA repair enzymes.

Inhibitors of DNA repair enzymes may be a useful tool for the potentiation of cancer chemotherapy, but also may be used in mechanistic studies on DNA damage recognition. The search for the inhibitors of repair enzymes among DNA base analogs resulted in finding $\mathrm{O}^{6}$-benzylguanine as a potent inhibitor of $\mathrm{O}^{6}$-alkylguanine DNA-alkyltransferase, the compound which enhances the toxicity of anticancer alkylating chemotherapeutics (Dolan \& Pegg, 1997), and currently is in clinical trials (Schold et al., 2004). Our previous studies on the recognition of alkylated bases have shown that 3-ethyl-, 3-propyl-, 3-butyl-, and 3-benzyladenine inhibit Escherichia coli alkylpurine DNA glycosylase I, the TagA protein, but not the $E$. coli alkylpurine DNA glycosylase II, AlkA, nor its human homolog, ANPG. A more polar derivative, 3-hydroxyethyladenine did not affect TagA, suggesting that hydrophobic interactions are involved in the mechanism of inhibition and/or recognition and excision of alkylated purines by the TagA protein (Tudek et al., 1998). This conclusion was further confirmed after resolution of the enzyme's crystal structure, which showed that the TagA glycosylase possesses a unique, deep, aromatic pocket, binding $3 \mathrm{MeA}$ (Drohat et al., 2002), which in other repair glycosylases of alkylated bases is much wider and less restricted to hydrophobic interactions.

The rationale of this study was to search for base analogs inhibiting the Fpg protein (formamidopyrimidine-DNA glycosylase) from $E$. coli because a number of DNA lesions in- duced by the drugs used in cancer chemotherapy (e.g. thiotepa) are substrates for the Fpg protein (Cussac \& Laval, 1996; Gros et al., 2002), and structural homologues of the Fpg protein have recently been found in mammalian cells (Hazra et al., 2002a; 2002b; Das et $a l ., 2004)$. We investigated the inhibition of the Fpg protein by 2,4,5,6-substituted pyrimidines and 2,6-substituted purines. We also investigated the effect of secondary DNA structure on the effectiveness of DNA processing by the Fpg and other DNA glycosylases of oxidized pyrimidines (Nth) and alkylated bases (bacterial TagA, AlkA, and human ANPG proteins) (reviewed in Gros et al., 2002) as well as bacterial AP endonuclease (Xth). For this purpose we used tryptophan pyrolysate, Trp-P-1, which was shown to change the secondary DNA structure into non-B, non-Z (Inohara et al., 1995).

The Fpg protein is an E. coli DNA glycosylase/AP lyase, which removes from DNA a broad spectrum of oxidized and alkylated bases: 8-oxoguanine, unsubstituted and substituted imidazole ring-opened purines introduced into DNA by hydroxyl radicals (e.g. FapyG, FapyA; Boiteux et al., 1992; Jurado et al., 1998) as well as by chemical carcinogens, including anticancer drugs (e.g. Fapy-7MeG, Fapy-7EtG, Fapy-7aminoethylG; Tudek et al., 1998; Cussac \& Laval, 1996). Fpg has two additional activities: (i) it cleaves DNA at abasic (AP) sites by $\beta-\delta$-elimination (Bailly et al., 1989); and (ii) displays a dRPase activity (Graves et al., 1992) which removes the $5^{\prime}$ ter- 
minal deoxyribose phosphate from DNA incised by an AP endonuclease. The Fpg protein contacts six bases in the repaired strand and one base opposite the lesion in the complementary strand. The enzyme does not recognize lesions paired with adenine (Tchou et al., 1991; Speina et al., 2001) or lesions in Z-DNA (Lagravère et al., 1984). In mammalian cells the Fpg protein has two structural/functional homologues - NEIL1 and NEIL2, which similarly to the Fpg protein use the N-terminal Pro as the active site, and utilize two DNA binding motifs, a helix-two-turn-helix and a zinc finger (Das et al., 2004). Both enzymes excise oxidized pyrimidines from DNA, but NEIL1 additionally removes FapyG and FapyA (Hazra et al., 2002b).

In $E$. coli the major glycosylase/AP lyase excising oxidized pyrimidines from DNA and, to a lesser extent, some Fapy lesions is the Nth protein (Dizdaroglu et al., 1993; 2000). The enzyme has an iron-sulfur cluster, a helix-turn-helix motif for DNA binding, and a deep cleft between two domains for substrate binding (Kuo et al., 1992a, 1992b). The enzyme cleaves AP-sites by $\beta$-elimination mechanism (reviewed by Gros et al., 2002).

DNA glycosylases of alkylated bases are monofunctional enzymes which remove alkylated bases, but do not cleave DNA at AP-sites. E. coli has two such enzymes: constitutive TagA protein, which specifically excises $3 \mathrm{MeA}$ and $3 \mathrm{MeG}$ from DNA (Thomas et al., 1982), and inducible AlkA glycosylase, which also recognizes $3 \mathrm{MeG}, 7 \mathrm{MeG}$ (Laval et al., 1981), 7EtG (Tudek et al., 1998) as well as hypoxanthine and $1, N^{6}$-ethenoadenine (Saparbaev \& Laval, 1994; Saparbaev et al., 1995). In eukaryotic cells, only one alkylpurine-DNA glycosylase (in humans - ANPG protein) has been found with the substrate specificity, but not structure, resembling that of the E. coli AlkA protein (O'Connor \& Laval, 1991; Saparbaev \& Laval, 1994; Saparbaev et al., 1995).

After the altered base is removed by DNA glycosylase, AP endonuclease cleaves the phos- phodiester backbone $5^{\prime}$ to the AP site. The major AP endonuclease in E. coli is the Xth protein. This enzyme possesses multiple catalytic activities: (1) a nucleotidyl hydrolase activity cutting $5^{\prime}$ to apurinic/apyrimidinic sites and urea residues in DNA; (2) a $3^{\prime}$ to $5^{\prime}$ exonuclease activity specific for double-stranded DNA; (3) an RNase $\mathrm{H}$ activity preferentially degrading the RNA strand of a DNA:RNA hybrid, and (4) an activity that can remove a number of $3^{\prime}$ termini from duplex DNA including 3'-phosphates, 3'-phosphoglycolate, 3'-phosphoglycolaldehyde, and 3'-trans-4-hydroxy-2-pentenal-5-phosphate residues (Kuo et al., 1993).

Trp-P-1 (3-amino-1,4-dimethyl-5H-pyrido[4,3-b]indole), together with other heterocyclic amines, like harman (1-methyl-9H-pyrido[3,4-b]indole) and norharman ( $9 H$-pyrido[3,4-b]indole) have been isolated from the charred parts of broiled fish and meat and found to be bacterial and mammalian mutagens as well as rodent carcinogens in concentrations highly exceeding the dietary intake of these substances (Mori et al., 1993). However, in low, nontoxic and nonmutagenic concentrations Trp-P-1 and other heterocyclic amines, namely Trp-P-2 (3-amino-1-methyl$5 H$-pyrido[4,3-b]indole) and harman have been shown to increase UV induced mutation frequencies in E. coli (Shimoi et al., 1992) or chromosomal aberrations in cultured mammalian cells (Sasaki et al., 1992) by inhibiting DNA repair, as later shown the nucleotide excision repair (Mori et al., 1993).

Here we show that the Fpg protein is inhibited by 2-thioxanthine (Fig. 1, compound 2) and to a lesser extent by 5,6-diamino-4-oxo2-thioxopyrimidine (compound 3 ) and 4,6-diamino-5-nitroso-2-oxopyrimidine (compound 4). We have also found that Trp-P-1 (Fig. 1, compound 1) differentially inhibits excision of alkylated bases by DNA glycosylases and incision activities of the Fpg and Nth DNA glycosylases as well as E. coli Xth AP endonuclease. 


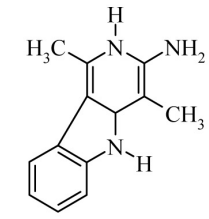

3-amino-1,4-dimethyl-2H-pyrido[4,3-b]indole (Trp-P-1)

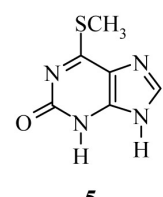

6-methylthio-2-oxopurine<smiles>Nc1[nH]c(=S)[nH]c(=O)c1[N+](=O)[O-]</smiles>

6-amino-5-nitroso-4-oxo-2-thioxopyrimidine<smiles>Cn1c(N)cc(=O)[nH]c1=O</smiles>

13

6-amino-1-methyluracil<smiles>O=c1[nH]c(=S)[nH]c2[nH]cnc12</smiles>

2-thioxanthine<smiles>Cc1nc(=O)[nH]c2c1ncn2C</smiles>

9-methyl-6-methylthio-2-oxopurine<smiles>CSc1nc(N)c(N=O)c(N)n1</smiles>

10

4,6-diamino-2-methylthio-5-nitrosopyrimidine<smiles>Nc1[nH]c(=S)[nH]c(=O)c1N</smiles>

3

5,6-diamino-4-oxo5,6-diamino-4-oxo-
2-thioxopyrimidine<smiles>Cn1cnc2c1c([Si])nc(=O)n2C</smiles>

7

3,7-dimethyl-6-methylthio-2-oxopurine<smiles>CSc1nc(N)c(N)c(=O)[nH]1</smiles>

$$
11
$$

5,6-diamino-2-methylthio-4-oxopyrimidine<smiles>CNc1nc(=O)[nH]c(NC)c1[N+](=O)[O-]</smiles>

$$
15
$$<smiles>Nc1nc(=O)[nH]c(N)c1N</smiles>

4

4,6-diamino-5-nitroso2-oxopyrimidine<smiles>CSc1nc(=O)n(C)c2c1ncn2C</smiles>

3,9-dimethyl-6-methylthio-2-oxopurine<smiles>Nc1nc(=O)[nH]c(N)c1N</smiles>

12

2-oxo-4,5,6-triaminopyrimidine<smiles>CNc1[nH]c(=O)nc(N)c1N</smiles>

$$
17
$$

4,5-diamino-6-methylamino-2-oxopyrimidine<smiles>O=c1cc(Cl)[nH]c(=O)[nH]1</smiles>

14

$$
\begin{gathered}
15 \\
\begin{array}{l}
\text { 4,6-di(methylamino)-5- } \\
\text { nitroso-2-oxopyrimidine }
\end{array}
\end{gathered}
$$

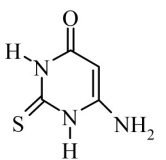

16

6-amino-4-oxo-2thioxopyrimidine

Figure 1. Chemical structures of compounds used in the present study.

\section{MATERIALS AND METHODS}

Reagents. Radiolabeled methylnitrosourea, $\left[{ }^{3} \mathrm{H}\right] \mathrm{MNU}(18 \mathrm{Ci} / \mathrm{mmol})$ was obtained from Amersham. Trp-P-1 was a kind gift of Dr. K. Wakabayashi (National Cancer Center Research Institute, Tokyo, Japan). Base analogs (see Fig. 1 compounds: 2-18) were obtained according to previously described procedures: compounds 2, 3, 9 (Beaman, 1954); 4, 12 (Bendich et al., 1948); 5 (Yamazaki et al., 1968); 6 (Lichtenberg et al.,
1972); 7 (Hayashi et al., 1980); 8 (Kazimierczuk \& Shugar, 1974); 10, 11 (Taylor \& Chain, 1952); 13 (Papesch \& Schroeder, 1951); 14, 15 (Kazimierczuk et al., 1972); 16 (Traube, 1904); 17 (Pfleiderer \& Fink, 1962); 18 (Huebsch \& Pfleiderer, 1988). The purity of the compounds was ascertained by TLC, UV, and mass spectra analysis (not shown). pBR322 plasmid DNA was isolated from $\mathrm{DH} 5 \alpha E$. coli strain according to the standard alkaline lysis procedure (Sambrook et al., 1989). 
Enzymes. E. coli formamidopyrimidine DNA glycosylase (the Fpg protein), alkylpurine DNA glycosylases (the TagA, AlkA, and ANPG proteins), and thymine glycol DNA glycosylase (the Nth protein) were purified according to standard procedures with minor modifications (Boiteux et al., 1987; Tudek et al., 1998; O’Connor \& Laval, 1990; Dizdaroglu et al., 1993). Bacterial exonuclease III (the Xth protein) was obtained from Promega (Maddison, WI, U.S.A.). Protein content was quantified as described by Bradford (1976).

Modification of DNA. $\left[{ }^{3} \mathrm{H}\right] \mathrm{MNU}-\mathrm{DNA}$ and $\left[{ }^{3} \mathrm{H}\right] \mathrm{MNU}-$ poly[d(G-C)] were prepared by alkylation of respective polynucleotides with $\left[{ }^{3} \mathrm{H}\right] \mathrm{MNU}$ as described (Boiteux et al., 1984). $\left[{ }^{3} \mathrm{H}\right]$ FapyMe-poly[d(G-C)] was obtained by imidazole ring opening of $\left[{ }^{3} \mathrm{H}\right] \mathrm{MNU}$ poly[d(G-C)] as described (Laval, 1977; Boiteux et al., 1984).

DNA of pBR322 plasmid was oxidized by an 8-oxoG inducing agent as follows: to $20 \mu \mathrm{g}$ of plasmid DNA in $10 \mathrm{mM}$ Tris $/ \mathrm{HCl}, \mathrm{pH} 8$ (50 $\mu \mathrm{l})$, methylene blue was added to a final concentration of $3.12 \mu \mathrm{M}$ and the mixture was irradiated with visible light (bulb $200 \mathrm{~W}$ ) for $10 \mathrm{~min}$ in an open tube on ice. For DNA depurination, $100 \mu \mathrm{g}$ of plasmid DNA in 100 $\mathrm{mM}$ sodium acetate buffer, $\mathrm{pH} 4.8(120 \mu \mathrm{l})$ was incubated at $70^{\circ} \mathrm{C}$ for $30 \mathrm{~min}$, followed by cooling below $30^{\circ} \mathrm{C}$ for $1 \mathrm{~h}$. Oxidized or depurinated DNA was pelleted with ice-cold ethanol and suspended in water.

DNA glycosylase assay. The AlkA and TagA protein standard reaction mixture $(50 \mu \mathrm{l})$ contained $\left[{ }^{3} \mathrm{H}\right] \mathrm{MNU}-\mathrm{DNA}$ ( 5 pmols of alkylated bases), $70 \mathrm{mM}$ Hepes/KOH, $\mathrm{pH} 7.8$, $1 \mathrm{mM}$ EDTA, $1 \mathrm{mM}$ dithiothreitol, 5\% glycerol. For ANPG this buffer was supplemented with $100 \mathrm{mM} \mathrm{KCl}$. The Fpg protein incubation mixture contained $\left[{ }^{3} \mathrm{H}\right] \mathrm{FapyMe}$-poly[d(G-C)] (5 pmols of alkylated bases), $70 \mathrm{mM}$ Hepes/ KOH, pH 7.6, $100 \mathrm{mM} \mathrm{KCl,} 2 \mathrm{mM}$ EDTA. The substrates were incubated at $37^{\circ} \mathrm{C}$ with an amount of enzyme which ensured that after reaction no more than $50 \%$ of sub- strate was used, then $50 \mu \mathrm{l}$ of DNA/BSA ( 0.5 $\mathrm{mg} / \mathrm{ml}$ calf thymus DNA, $0.26 \mathrm{mg} / \mathrm{ml}$ bovine serum albumin, $250 \mathrm{mM} \mathrm{NaCl}$ ) was added to stop the reaction. The DNA was precipitated with $300 \mu \mathrm{l}$ of cold ethanol and the enzyme activity was calculated on the basis of the amount of liberated modified bases assayed in supernatants by liquid scintillation.

DNA glycosylase and AP endonuclease assay. Fpg, Nth, and Xth standard reaction mixtures $(50 \mu \mathrm{l})$ contained oxidized or depurinated pBR322 DNA (50 $\mu \mathrm{g})$ in an appropriate buffer (70 mM Hepes/KOH, pH 7.6, $100 \mathrm{mM} \mathrm{KCl}, 2 \mathrm{mM}$ EDTA for the Fpg protein. The Nth protein reaction buffer comprised $50 \mathrm{mM}$ Tris/ $\mathrm{HCl}, \mathrm{pH} 7.8,50 \mathrm{mM} \mathrm{KCl}$, $2 \mathrm{mM}$ EDTA. The Xth protein buffer was supplied by the enzyme's manufacturer). The substrates were incubated at $37^{\circ} \mathrm{C}$ with an amount of enzyme which ensured that after reaction no more than $50 \%$ of substrate was digested and aliquots of each reaction were separated on $0.8 \%$ agarose gels containing ethidium bromide. Images of the gels were recorded using the UVP Gel Documentation System (UVP Inc., Upland, CA, U.S.A.).

Inhibition of DNA glycosylase and AP endonuclease activity by base analogs and Trp-P-1. DNA glycosylase reaction mixtures containing $\left[{ }^{3} \mathrm{H}\right] \mathrm{MNU}-\mathrm{DNA}$ or $\left[{ }^{3} \mathrm{H}\right]-$ FapyMe-poly[d(G-C)] were supplemented with different concentrations of Trp-P-1 or base analogs $(1 \mu \mathrm{M}$ to $5 \mathrm{mM})$. Following 10 min incubation at $37^{\circ} \mathrm{C}$, the DNA was ethanol precipitated in the presence of DNA/BSA and liberated bases assayed as described above. Concentration of compounds, inhibiting 50\% of enzymes' activities $\left(\mathrm{IC}_{50}\right)$ were calculated. DNA glycosylase and/or AP endonuclease reaction mixtures containing depurinated or oxidized pBR322 DNA were supplemented with $1 \mathrm{mM}$ Trp-P-1 and incubated at $37^{\circ} \mathrm{C}$ for $10 \mathrm{~min}$. The enzyme activity was judged on the basis of the relative band intensity of the $c c c$ and $o c$ DNA forms after agarose gel electrophoresis. 
Estimation of $K_{i}$ for Fpg glycosylase activity inhibition by 2-thioxanthine. Reactions were conducted in $10 \mu \mathrm{l}$ sample volume which contained the substrate $(2.5-12 \mathrm{nM})$, $70 \mathrm{mM}$ Hepes/KOH, pH 7.6, $100 \mathrm{mM} \mathrm{KCl,} 2$ $\mathrm{mM}$ EDTA, $1 \%$ glycerol, BSA $(20 \mu \mathrm{g} / \mathrm{ml})$, 2-thioxanthine (4 or $5 \mu \mathrm{M}$ ) in $\mathrm{Me}_{2} \mathrm{SO}$ (final concentration $16 \%$ ), and $0.4 \mathrm{ng}$ of the Fpg protein added last. The samples were incubated at $37^{\circ} \mathrm{C}$ for $10 \mathrm{~min}$ and reactions were stopped by the addition of $90 \mu \mathrm{l}$ DNA/BSA. DNA was precipitated and liberated bases measured as above. Kinetic constants were calculated using a program based on the Eisenthall-Cornish-Bowden nonparametric algorithm (Kamiński \& Domino, 1987). The $K_{\mathrm{i}}$ value was calculated from replots of ordinate and abscissa intercepts.

\section{RESULTS AND DISCUSSION}

The Fpg, TagA, AlkA, and Nth proteins were purified to homogeneity according to standard procedures (Boiteux et al., 1987; Tudek et al., 1998; Dizdaroglu et al., 1993). This yielded proteins of high purity: a single band, as judged by polyacrylamide gel electrophoresis (not shown), and the proteins were further used for inhibition studies. We found that the classical excision product of the Fpg protein Fapy-7MeG very weakly inhibited the Fpg activity; at $1 \mathrm{mM}$ concentration the excision of Fapy-7MeG from DNA was decreased only by $16 \%$ and at $5 \mathrm{mM}$ by $32 \%$. In order to look for more efficient inhibitors of this activity, we tested seventeen substituted purine and pyrimidine intermediates for purine synthesis (Fig. 1, compounds 2-18). The aim of this search was to find a possible "leading structure" for further studies on the inhibitors of the Fpg glycosylase. Three of them (compounds $\mathbf{2}, \mathbf{3}$, and $\mathbf{4}$ ) revealed inhibitory properties. The other compounds, tested in up to 1 $\mathrm{mM}$ concentration, had no effect on the enzyme activity. The most efficient inhibitor was a purine analog, 2-thioxanthine (2-thio- 6-oxopurine, compound 2). It inhibited $50 \%$ of the enzyme activity $\left(\mathrm{IC}_{50}\right)$ at $17.1 \mu \mathrm{M}(\mathrm{Ta}-$ ble 1) and $80 \%$ at $50 \mu \mathrm{M}$. Because of the high

Table 1. Inhibition of Fpg glycosylase activity by various base analogs*

\begin{tabular}{lc}
\hline Base analog & $\mathrm{IC}_{50}[\mu \mathrm{M}]$ \\
\hline 2-Thioxanthine & $17.1 \pm 0.6$ \\
$\begin{array}{l}\text { 5,6-Diamino-4-oxo-2-thioxo- } \\
\text { pyrimidine }\end{array}$ & $343.3 \pm 58.6$ \\
$\begin{array}{l}\text { 4,6-Diamino-5-nitroso-2- } \\
\text { oxopyrimidine }\end{array}$ & $350 \pm 24.4$ \\
\hline
\end{tabular}

${ }^{*}$ Data from three assays are presented as mean \pm S.D.

substrate usage in kinetics experiments (20-60\%), for the calculation of the Fpg protein kinetics, mean substrate concentrations (arithmetic mean of initial and final concentration) and mean velocity (fmol substrate used $/ \mathrm{min}$ ) were used. The measured $K_{\mathrm{m}}$ value of the Fpg protein activity was $2.43 \pm$ $0.68 \mathrm{nM}$, whereas $V_{\max }$ was $3.19 \pm 0.41$ $\mathrm{fmol} / \mathrm{min}$. The obtained $K_{\mathrm{m}}$ values for Fapy-7MeG excision are similar to the values obtained in other studies, $7 \mathrm{nM}$ (Tudek et al., 1998), and $10 \mathrm{nM}$ (Jurado et al., 1998). For other Fpg glycosylase substrates the $K_{\mathrm{m}}$ values are also low, e.g. for 8-oxoG excision from the 8-oxoG:C pair $K_{\mathrm{m}}$ values varying between $4 \mathrm{nM}$ and $16 \mathrm{nM}$ have been reported (Jurado et al., 1998; Duarte et al., 2000; Tchou et al., 1994), and for excision of pyrimidine ring-opened $1, N^{6}$-ethenoadenine derivative the $K_{\mathrm{m}}$ is $6 \mathrm{nM}$ (Speina et al., 2001).

$K_{\mathrm{i}}$ of Fpg inhibition by 2-thioxanthine (Fig. 1, compound 2) was $4.44 \pm 0.15 \mu \mathrm{M}$. The character of inhibition was found to be uncompetitive (catalytic, Fig. 2), which means that 2-thioxanthine is able to bind only the Fpg protein-DNA complex, but not the free enzyme. This suggests that binding of the Fpg protein to DNA significantly changes the protein conformation, creating the recognition site for the inhibitor. A comparative study of crystal models of Fpg glycosylases obtained 


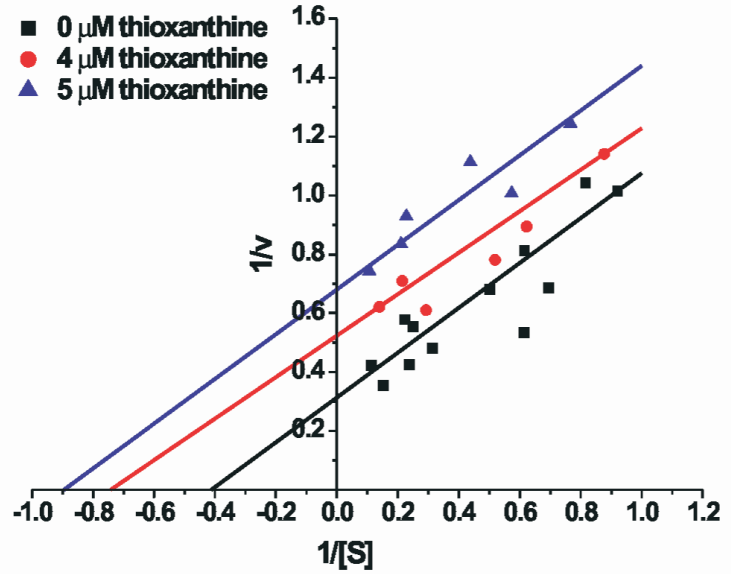

Figure 2. Lineweaver-Burk plot for the uncompetitive (catalytic) inhibition of Fpg glycosylase activity by 2-thioxanthine

The Fpg protein standard reaction mixtures containing $\left[{ }^{3} \mathrm{H}\right]$ FapyMe-poly[d(G-C)] were supplemented with 4 or $5 \mu \mathrm{M}$ thioxanthine and incubated at $37^{\circ} \mathrm{C}$ for 10 min. Following DNA precipitation liberated bases were measured and the enzyme activity assayed. Plots for non-inhibited and inhibited enzyme were calculated by the use of the Eisenthall-Cornish-Bowden nonparametric algorithm. $K_{i}$ value was calculated from ordinate and abscissa intercepts.

from different bacteria species, either as free enzymes or in complex with an abasic site-containing DNA, shows that the Fpg protein reveals high dynamics upon binding to damaged DNA (Amara et al., 2004). Our results suggest that the enzyme-substrate complex binds to the inhibitor leading to a ternary complex which is enzymatically inactive. It is possible that the damaged base influences the dynamics of the whole enzyme. The site of 2-thioxanthine binding is unknown, however it is possible that once the inhibitor is bound to the enzyme-substrate complex, another conformational change takes place causing enzyme inhibition.

Two other base analogs, 5,6-diamino-4-oxo2-thioxopyrimidine and 4,6-diamino-5-nitroso2-oxopyrimidine (Fig. 1, compound $\mathbf{3}$ and 4, respectively) were weaker inhibitors. Their $\mathrm{IC}_{50}$ values were $343.3 \pm 58.6$ and $350 \pm$ $24.4 \mu \mathrm{M}$, respectively (Table 1 ). The character of the inhibition was not studied for these compounds.

We also investigated the effect of the modification of the secondary DNA structure on the activity of different base excision repair enzymes. 3-Amino-1,4-dimethyl-5H-pyrido[4,3-b]indole (tryptophan pyrolysate, Trp-P-1; Fig. 1, compound 1) belongs to a class of heterocyclic amines that have been isolated from cooked food and found to be mutagenic and carcinogenic (Watanabe \& Ohta, 1993; Ohgaki et al., 1986). Heterocyclic amines intercalate into DNA and change the structure of the double helix into a non-B, non-Z form (Inohara et al.,

Table 2. Inhibitory effect of Trp-P-1 on DNA glycosylase activity*

\begin{tabular}{lc}
\hline DNA glycosylase & $\mathrm{IC}_{50}[\mu \mathrm{M}]$ \\
\hline Fpg & $187.5 \pm 46$ \\
TagA & $96 \pm 15.6$ \\
AlkA & $1 \pm 0.1$ \\
ANPG & $76.5 \pm 19.1$ \\
\hline
\end{tabular}

*Data from three assays are presented as mean \pm S.D. Fpg, $E$. coli formamidopyrimidine DNA glycosylase; TagA and AlkA, E. coli alkylpurine DNA glycosylase I and II, respectively; ANPG, human alkylpurine DNA glycosylase.

1995). We studied the release of alkylated bases from radiolabeled polynucleotides or DNA by the Fpg, TagA, AlkA, and ANPG proteins in the presence of Trp-P-1 (Table 2). Trp-P-1 inhibited the glycosylase activity of the Fpg protein by $50 \%$ at $187.5 \mu \mathrm{M}$, and almost completely at $500 \mu \mathrm{M}$. The values of $\mathrm{IC}_{50}$ for the TagA and ANPG proteins were 96 $\pm 15.6 \mu \mathrm{M}$ and $76.5 \pm 19.1 \mu \mathrm{M}$, respectively. Trp-P-1 most efficiently inhibited the activity of the AlkA glycosylase $\left(\mathrm{IC}_{50}=1 \pm 0.1 \mu \mathrm{M}\right)$. All of the above DNA glycosylases, except for the Fpg protein, require double stranded DNA as a substrate, and thus may be more sensitive to DNA structure change than the Fpg protein, which can excise damaged bases also from a single stranded substrate, al- 
though with about 100-fold lower efficiency (Boiteux et al., 1990).

We also used a plasmid system in which we measured conversion of the supercoiled ( $c c c$ ) to the relaxed $(o c)$ form upon nicking by AP lyases or AP endonuclease at AP sites caused by the release of the damaged base by DNA glycosylase. When the plasmid DNA was modified by methylene blue in the presence of visible light (a system generating almost ex- nuclease) and bifunctional DNA glycosylases (Fpg and Nth proteins). Using depurinated DNA as a substrate, it was found that the incision activity of the Fpg, Nth and Xth proteins was completely inhibited by $1 \mathrm{mM}$ Trp-P-1 (Fig. 3B). Judging from the ratio of the $c c c$ to oc plasmid forms, this inhibition was less efficient for AP endonuclease than for the AP lyase activities of the Fpg and Nth proteins.

DNA conformation is a general factor affect-

\section{A}

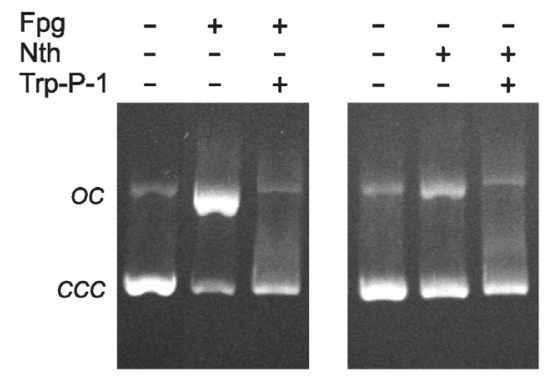

B

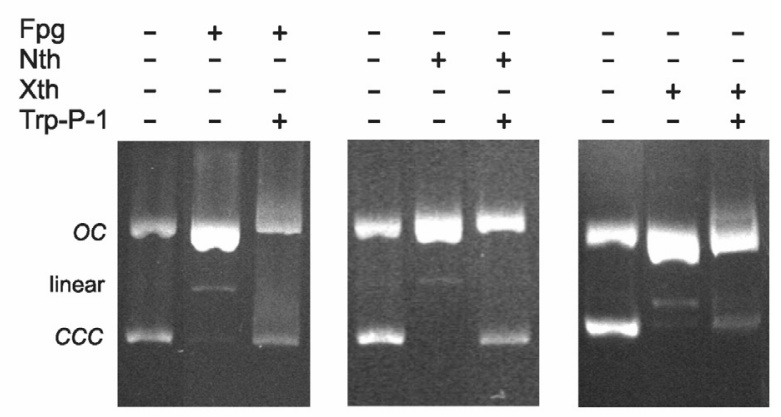

Figure 3. Inhibitory effect of Trp-P-1 on DNA glycosylase activity and strand scission by E. coli Fpg and Nth proteins, and on strand scission by Xth protein.

Oxidized (A) or depurinated (B) pBR322 plasmid DNA was treated with $1 \mathrm{mM}$ Trp-P-1 at $37^{\circ} \mathrm{C}$ for 10 min and incubated with enzyme for $10 \mathrm{~min}$. The reacted DNA was analyzed by agarose gel electrophoresis. Each experiment was performed in duplicate and results from one experiment are shown. oc, relaxed (open circular) DNA; ccc, supercoiled (covalently closed circular) DNA.

clusively 8-oxoguanine; Tudek et al., 1993), it was found that the activity of the Fpg and Nth proteins against the oxidized DNA was abolished in the presence of $1 \mathrm{mM}$ Trp-P-1 (Fig. 3A). This suggests that repair of 8-oxoG and other oxidized bases recognized by the studied glycosylases/AP lyases is inhibited by Trp-P-1.

We also investigated if Trp-P-1 would influence incision of DNA at abasic sites by the Xth protein (the major $E$. coli AP endo- ing the activity of DNA repair enzymes, however, the same factor may have divergent effects on different repair systems. The Fpg protein and $\mathrm{O}^{6}$-methylguanine DNA methyltransferase are inactive towards the substrate DNA in Z-form (Lagravère et al., 1984; Boiteux et al., 1985). Excision of pyrimidine dimers and 6-4 photoproducts from UV irradiated DNA by UvrABC nuclease and T4 endonuclease $\mathrm{V}$ was decreased in the presence of Trp-P-1 (Mori et al., 1993; Shimoi et al., 1996). 
Other intercalating agents, like ethidium bromide or ellipticine increased the activity of uracil-DNA glycosylase about 2-fold (Leblanc et al., 1982), probably by promoting formation of ssDNA fragments, for which the enzyme has a higher affinity than for dsDNA. Similarly, ethidium bromide stimulates release of $3 \mathrm{MeA}$ from nucleosomes by mammalian cell extracts and partially purified alkylpurine-DNA glycosylase (Price et al., 1983), probably by relaxing the nucleosome structure and abolishing the steric hindrance of histones for repair enzymes. In contrast, correction of the G:T mismatch by hMutS $\alpha$ was inhibited by low concentration of ethidium bromide $\left(\mathrm{IC}_{50}-30 \mu \mathrm{M}\right)$ and intercalating anticancer drugs like adriamycine, probably by preventing mismatch binding (Larson \& Drummond, 2001).

Taken together the results show that 2-thioxanthine inhibits excision of Fapy-7MeG by the Fpg protein by an uncompetitive mode, which suggests substantial dynamics of the Fpg protein upon substrate binding. We have also shown that change(s) of DNA secondary structure by Trp-P-1 may significantly influence two classes of DNA repair events: the excision of damaged DNA bases by several glycosylases, as well as the incision of DNA at AP sites by AP lyases and AP endonucleases. Thus, similarly to the inhibition of UV-induced DNA damage repair, Trp-P-1 might exert an inhibitory effect also on base excision repair, and its consumption in the human diet may also increase mutation rate caused by alkylation and oxidative DNA damage.

We thank Dr. Keiji Wakabayashi (Carcinogenesis Division, National Cancer Center Research Institute, Tokyo, Japan) for a kind gift of Trp-P-1. The authors would like to express the gratitude to Professor Jarosław T. Kuśmierek (Institute of Biochemistry and Biophysics, PAS) for many helpful discussions.

\section{R E F E R E N C E S}

Amara P, Serre L, Castaing B, Thomas A. (2004) Insights into the DNA repair process by the formamidopyrimidine-DNA glycosylase investigated by molecular dynamics. Protein Sci.; 13: 2009-21.

Bailly V, Verly WG, O’Connor T, Laval J. (1989) Mechanism of DNA strand nicking at apurinic/apyrimidinic sites by Escherichia coli [formamidopyrimidine]DNA glycosylase. Biochem J.; 262: 581-9.

Beaman AG. (1954) New syntheses of purine. $J$ Am Chem Soc.; 76, 5633-6.

Bendich A, Tinker JF, Brown GB. (1948) A synthesis of isoguanine labeled with isotopic nitrogen. J Am Chem Soc.; 70, 3109-13.

Boiteux S, Belleney J, Roques BP, Laval J. (1984) Two rotameric forms of open ring 7 methylguanine are present in alkylated polynucleotides. Nucleic Acids Res.; 12: 5429-39.

Boiteux S, Costa de Oliveira R, Laval J. (1985) The Escherichia coli $\mathrm{O}^{6}$-methylguanine-DNA methyltransferase does not repair promutagenic $\mathrm{O}^{6}$-methylguanine residues when present in Z-DNA. $J$ Biol Chem.; 260: 8711-5.

Boiteux S, O’Connor TR, Laval J. (1987) Formamidopyrimidine-DNA glycosylase of Escherichia coli: cloning and sequencing of the fpg structural gene and overproduction of the protein. EMBO J.; 6: 3177-83.

Boiteux S, O'Connor TR, Lederer F, Gouyette A, Laval J. (1990) Homogeneous Escherichia coli FPG protein. A DNA glycosylase which excises imidazole ring-opened purines and nicks DNA at apurinic/apyrimidinic sites. $J$ Biol Chem.; 265: 3916-22.

Boiteux S, Gajewski E, Laval J. Dizdaroglu M. (1992) Substrate specificity of the Escherichia coli Fpg protein (formamidopyrimidine-DNA glycosylase): excision of purine lesions in DNA produced by ionizing radiation or photosensitization. Biochemistry.; 31: 106-10.

Bradford MM. (1976) A rapid and sensitive method for the quantitation of microgram 
quantities of protein utilising the principle of protein-dye binding. Anal Biochem.; 72: $248-55$.

Cussac C, Laval F. (1996) Reduction of the toxicity and mutagenicity of aziridine in mammalian cells harboring the Escherichia coli fpg gene. Nucleic Acids Res.; 24: 1742-6.

Das A, Rajagopalan L, Mathura VS, Rigby SJ, Mitra S, Hazra TK. (2004) Identification of a zinc finger domain in the human NEIL2 (Nei-like-2) protein. J Biol Chem.; 279: 47132-8.

Dizdaroglu M, Laval J, Boiteux S. (1993) Substrate specificity of the Escherichia coli endonuclease III: excision of thymine- and cytosine-derived lesions in DNA produced by radiation-generated free radicals. Biochemistry.; 32: 12105-11.

Dizdaroglu M, Bauche C, Rodriguez H, Laval J. (2000) Novel substrates of Escherichia coli Nth protein and its kinetics for excision of modified bases from DNA damaged by free radicals. Biochemistry.; 39: 5586-92.

Dolan ME, Pegg AE. (1997) $0^{6}$-benzylguanine and its role in chemotherapy. Clin Cancer Res.; 3: 837-47.

Drohat AC, Kwon K, Krosky DJ, Stivers JT. (2002) 3-Methyladenine DNA glycosylase I is an unexpected helix-hairpin-helix superfamily member. Nat Struct Biol.; 9: 659-64.

Duarte V, Gasparutto D, Jaquinod M, Cadet J. (2000) In vitro DNA synthesis opposite oxazolone and repair of this DNA damage using modified oligonucleotides. Nucleic Acids Res.; 28: 1555-63.

Graves RJ, Felzenszwalb I, Laval J, O’Connor TR. (1992) Excision of 5'-terminal deoxyribose phosphate from damaged DNA is catalyzed by the Fpg protein of Escherichia coli. J Biol Chem.; 267: 14429-35.

Gros L, Saparbaev MK, Laval J. (2002) Enzymology of the repair of free radicals-induced DNA damage. Oncogene.; 21: 8905-25.

Hayashi M, Hisanaga Y, Yamauchi K, Kinoshita M. (1980) Methylation of thiouracils and thioxanthines with trimethyl phosphate. Syn Comm.; 10: 791-8.

Hazra TK, Izumi T, Boldogh I, Imhoff B, Kow YW, Jaruga P, Dizdaroglu M, Mitra S. (2002a) Identification and characterization of a human DNA glycosylase for repair of modified bases in oxidatively damaged DNA. Proc Natl Acad Sci USA.; 99: 3523-8.

Hazra TK, Kow YW, Hatahet Z, Imhoff B, Boldogh I, Mokkapati SK, Mitra S, Izumi T. (2002b) Identification and characterization of a novel human DNA glycosylase for repair of cytosine-derived lesions. J Biol Chem.; 277: 30417-20.

Huebsch W, Pfleiderer W. (1988) 150. Pteridines. Synthesis and properties of 8-substituted 2-thiolumazines. Helv Chim Acta.; 71: 1379-91.

Inohara T, Tarui M, Mihara Y, Doi M, Ishida T. (1995) Binding specificity of mutagenic tryptophan pyrolysates for DNA conformation: spectroscopic and viscometric studies. Chem Pharm Bull.; 43: 1607-13.

Jurado J, Saparbaev M, Matray TJ, Greenberg MM, Laval J. (1998) The ring fragmentation product of thymidine C5-hydrate when present in DNA is repaired by the Escherichia coli Fpg and Nth proteins. Biochemistry.; 37: 7757-63.

Kamiński ZW, Domino EF. (1987) Computer program for calculation of kinetic and pharmacologic parameters using a 'direct linear plot' derived algorithm. Comp Meth Progr Biomed.; 24: 41-5.

Kazimierczuk Z, Shugar D. (1974) Preparation of some $N$-methyl isoguanines via 6-methylthio-2-oxopurines, and of 8-methylisoguanine. Acta Biochim Polon.; 21: 455-63.

Kazimierczuk Z, Lipski M, Shugar D. (1972) Intermediates in the synthesis of purines and pteridines. Selective hydrolysis of chloropyrimidines. Acta Biochim Polon.; 19: 359-66.

Kuo CF, McRee DE, Cunningham RP, Tainer JA. (1992a) Crystallization and crystallographic characterization of the iron-sulfur-containing DNA-repair enzyme 
endonuclease III from Escherichia coli. J Mol Biol.; 227: 347-51.

Kuo CF, McRee DE, Fisher CL, O’Handley SF, Cunningham RP, Tainer JA. (1992b) Atomic structure of the DNA repair [4Fe-4S] enzyme endonuclease III. Science.; 258: 434-40.

Kuo CF, McRee DE, Cunningham RP, Tainer JA. (1993) Purification, crystallization and space group determination of DNA repair enzyme exonuclease III from $E$. coli. $J$ Mol Biol.; 229: 239-42.

Lagravère C, Malfoy B, Leng M, Laval J. (1984) Ring-opened alkylated guanine is not repaired in Z-DNA. Nature.; 310: 798-800.

Larson ED, Drummond JT. (2001) Human mismatch repair and $G^{*} T$ mismatch binding by hMutSalpha in vitro is inhibited by adriamycine, actinomycine $\mathrm{D}$, and nogalamycin. $J$ Biol Chem.; 276: 9775-83.

Laval J. (1977) Two enzymes are required from strand incision in repair of alkylated DNA. Nature.; 269: 829-32

Laval J, Pierre J, Laval F. (1981) Release of 7-methylguanine residues from alkylated DNA by extracts of Micrococcus luteus and Escherichia coli. Proc Natl Acad Sci USA.; 78: $852-5$.

Leblanc JP, Martin B, Cadet J, Laval J. (1982) Uracil-DNA glycosylase. Purification and properties of uracil-DNA glycosylase from Micrococcus luteus. J Biol Chem.; 257: 3477-83.

Lichtenberg D, Bergmann F, Neiman Z. (1972) Tautomerism and ionization processes in 6-thioxanthine and its $N$-methyl derivatives. J Chem Soc.; 1676-81.

Mori T, Shimoi K, Sasaki YF, Wakabayashi K, Nagao M, Kinae N. (1993)

3-Amino-1,4-dimethyl-5H-pyrido[4,3-b]indole (Trp-P-1) inhibits the removal of both cyclobutane dimers and (6-4) photoproducts from the DNA of ultraviolet-irradiated E. coli. Carcinogenesis.; 14: 1475-8.

O'Connor TR, Laval F. (1990). Isolation and structure of a cDNA expressing mammalian 3-methyladenine-DNA glycosylase. The EMBO J.; 9: 3337-42.
O'Connor TR, Laval J. (1991) Human cDNA expressing a functional DNA glycosylase excising 3-methyladenine and 7-methylguanine. Biochem Biophys Res Commun.; 176: 1170-77.

Ohgaki H, Hasegawa H, Kato T, Suenaga M, Ubukata M, Sato S, Takayama S, Sugimura T. (1986) Carcinogenicity in mice and rats of heterocyclic amines in cooked foods. Environ Health Perspect.; 67: 129-34.

Papesch V, Schroeder EF. (1951) Synthesis of 1-mono- and 1,3-disubstituted 6-aminouracils. diuretic activity. J Org Chem.; 16: 1879-90.

Pfleiderer W, Fink H. (1962) Umsetzungen mit 4-Chlorcytosin. Liebigs Ann Chem.; 657: 149-55.

Price JA, Heller E, Goldthwait DA. (1983) The release of 3-methyladenine from nucleosomal DNA by a 3-methyladenine DNA glycosylase. Carcinogenesis.; 4: 145-52.

Sambrook J, Fritsch EF, Maniatis T. (1989) Molecular Cloning, 2nd edn. Cold Spring Harbor Lab. Press. New York.

Saparbaev M, Laval J. (1994) Excision of hypoxanthine from DNA containing dIMP residues by the Escherichia coli, yeast, rat, and human alkylpurine DNA glycosylases. Proc Natl Acad Sci USA.; 91: 5873-7.

Saparbaev M, Kleibl K, Laval J. (1995) Escherichia coli, Saccharomyces cerevisiae, rat and human 3-methyladenine DNA glycosylases repair $1, N^{6}$-ethenoadenine when present in DNA. Nucleic Acids Res. 23: 3750-5.

Sasaki YF, Yamada H, Shimoi K, Kinae N, Tomita I, Matsumura H, Ohta T, Shirasu Y. (1992) Enhancing effects of heterocyclic amines and beta-carbolines on the induction of chromosome aberrations in cultured mammalian cells. Mutat Res.; 269: 79-95.

Schold SC Jr, Kokkinakis DM, Chang SM, Berger MS, Hess KR, Schiff D, Robins HI, Mehta MP, Fink KL, Davis RL, Prados MD. (2004) $\mathrm{O}^{6}$-benzylguanine suppression of $\mathrm{O}^{6}$-alkylguanine-DNA alkyltransferase in anaplastic gliomas. Neuro-oncol.; 6: 28-32.

Shimoi K, Kawabata H, Tomita I. (1992) Enhancing effect of heterocyclic amines and 
beta-carbolines on UV or chemically induced mutagenesis in E. coli. Mutat Res.; 268: 287-95.

Shimoi K, Miyamura R, Mori T, Todo T, Ohtsuka E, Wakabayashi K. (1996) 3-Amino-1,4-dimethyl-5H-pyrido[4,3-b]indole (Trp-P-1) inhibits the binding activity of T4 endonuclease V to UV-damaged DNA. Carcinogenesis.; 17: 1279-83.

Speina E, Cieśla JM, Wójcik J, Bajek M, Kuśmierek JT, Tudek B. (2001) The pyrimidine ring-opened derivative of $1, N^{6}$-ethenoadenine is excised from DNA by the Escherichia coli Fpg and Nth proteins. J Biol Chem.; 276: 21821-7.

Taylor EC, Chain CK. (1952) Pteridines VII. The Synthesis of 2-Alkylaminopteridines. $J$ Am Chem Soc.; 1644-7.

Tchou J, Kasai H, Shibutani S, Chung MH, Laval J, Grollman AP, Nishimura S. (1991) 8-Oxoguanine (8-hydroxyguanine) DNA glycosylase and its substrate specificity. Proc Natl Acad Sci USA.; 88: 4690-4.

Tchou J, Bodepudi V, Shibutani S, Antoshechkin I, Miller J, Grollman AP, Johnson F. (1994) Substrate specificity of Fpg protein. Recognition and cleavage of oxidatively damaged DNA. J Biol Chem.; 269: 15318-24.
Thomas L, Yang CH, Goldthwait DA. (1982) Two DNA glycosylases in Escherichia coli which release primarily 3-methyladenine. Biochemistry.; 21: 1162-9.

Traube W. (1904) Der Aufbau der Xanthinbasen aus der Cyanessigsaure. Synthese des Hypoxanthins and Adenins. Liebigs Ann Chem.; 331: 64-88.

Tudek B, Laval J, Boiteux S. (1993) SOS-independent mutagenesis in lac $Z$ induced by methylene blue plus visible light. Mol Gen Genet.; 236: 433-9.

Tudek B, Van Zeeland AA, Kuśmierek JT, Laval J. (1998) Activity of Escherichia coli DNA-glycosylases on DNA damaged by methylating and ethylating agents and influence of 3-substituted adenine derivatives. Mutat Res.; 407: 169-76.

Watanabe M, Ohta T. (1993) Analysis of mutational specificity induced by heterocyclic amines in the lacZ gene of Escherichia coli. Carcinogenesis.; 14: 1149-53.

Yamazaki A, Kumashiro I, Takenishi T, Ikehara M. (1968) Synthesis of thio-AICA, 6-thioxanthine, isoguanosine analogs and their ribosides. Chem Pharm Bull.; 16: 2172-81. 